\title{
A Study of the First-Year Academic Experience at a Growing Liberal Arts Institution
}

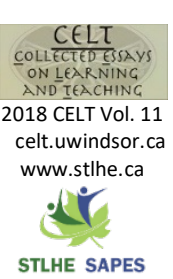

Robyne Hanley-Dafoe \& Cathy Bruce

DOI: $10.22329 /$ celt.v11i 0.4973

How can universities ensure that the first-year learning experiences are purposeful, personal, and transformative? This study explores challenges post-secondary institutions face in the everchanging landscape of first-year teaching and learning. It spanned 18 months and included surveys, reflections, and an environmental scan of 92 first-year course syllabi. The study captures the perspectives of faculty, staff and students, in both first and second year, in relation to their academic experiences, and includes recommendations for supporting both student retention and teaching and learning experiences.

Comment peut-on faire en sorte, dans les universités, que les expériences d'apprentissage des étudiants de première année soient significatives et personnelles et qu'elles aient un pouvoir de transformation? Cette étude explore les défis auxquels les établissements postsecondaires sont confrontés dans ce paysage mouvant que représentent l'apprentissage et l'enseignement de première année. D'une durée de 18 mois, l'étude a compris des sondages, des réflexions et une analyse contextuelle de 92 plans de cours de première année. On y voit s'exprimer le point de vue des professeurs, des employés et des étudiants de première et de deuxième année au sujet de leurs expériences universitaires. On y formule également des recommandations afin d'accroître le taux de rétention des étudiants et d'améliorer les expériences d'apprentissage et d'enseignement.

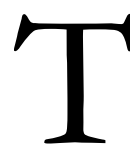

rent University was founded as a small undergraduate liberal arts university, positioned as an alternative institution to larger and more conservative universities. The University was built on the principles of liberalism in conjunction with small classes, personalized experiences, and collaborative models of teaching and learning. Faculty specifically designed the first-year learning experiences to be transformational for learners. This signature characteristic is still present, despite the fact that the University has grown substantially since its founding. Faculty continue to be invested in the student experience and make meaningful connections to their students. The development of a First-Year Caucus of faculty who meet to discuss challenges and successes in their firstyear courses exemplifies this engagement. Discussions with faculty of the First-Year Caucus suggest that, due to an increase in class sizes, combined with the increasing complexity of the needs of 21 st century students, it is becoming more challenging to achieve the outcomes of first-year courses. The First-Year Caucus wanted to work in collaboration with the Centre for Teaching and Learning to gather evidence 
of current practices and contexts in first-year courses. This was a key impetus for engaging in the First-Year Academic Experience Project. Studying the first-year academic experience is a complex problem with multiple competing factors that needed to be investigated to further understand the current context of first-year courses.

Members of the recently opened Centre for Teaching and Learning embarked on this collaborative project to begin to develop a deeper understanding of the first-year academic experience. Based on recommendations by first-year instructors, we set out to capture the perspectives of faculty, student support staff, and students in relation to their academic experiences in the first-year of learning at the University. The project also generated a series of recommendations for consideration with the broader goal of supporting student retention as well as quality teaching and learning experiences for both students and instructors.

The literature review provided here is purposely succinct (Boote \& Beile, 2005). It is not an exhaustive review of the current literature on firstyear learning experiences, but provides context for the project and the themes used in developing the questionnaires. The first-year learning experience has been predominantly studied within the frames of student transitions into university, student engagement, student motivation, student retention rates, and the 21 st century learner. The phenomenon of transitions refers to a movement or a change from one position to another. It is experienced by individuals as both short and long-term processes of adjustment, development and change (Latham \& Green, 1997; Kantanis, 2000). Transitions have long been recognized as challenging due to needed adjustments (e.g., rearranging emotions, roles and relationships) required by individuals during these transitory periods (Schlossberg, 1981). Engagement, similarly, has been found to be an important aspect of the schooling experience, both academically and socially. In a broad sense, student engagement can be described as a student's attitude toward schooling and their participation in school activities, including coursework in order to achieve learning outcomes (Krause \& Coates, 2008; Willms, 2003). Though there is conflicting research on whether engagement is directly connected to academic grades (Carini, Kuh \& Klein, 2006; Willms, 2003), research suggests that school engagement does contribute to student satisfaction, persistence (Asmar, Page \& Radloff, 2011), and a student's life after school, including economic success, health, and general well-being (Willms, 2003). Engagement is also closely tied to student motivation, or the student's desire to actively engage in the process of learning. Ames (1990) characterizes a student's motivation as the quality of involvement in learning and long-term commitment to the process of learning. Both engagement and motivation may contribute to retention. Parkin and Baldwin's (2009) research in Canada shows that approximately one out of every six students will not complete their studies and $14 \%$ of students will not complete their first-year. Workload, lack of motivation, and not feeling a part of the community (a sense of belonging) are all common reasons for why students may have decided to withdraw, making the successful transition of first-year students to upper year studies a primary concern for most universities (Nelson, Duncan, \& Clarke, 2009; Barnes, Macalpine, \& Munro, 2015).

As university communities are becoming increasingly diverse, institutions are adopting a more multi-faceted approach to addressing student needs and issues, prompting the need for the following updated, context-specific study. Research shows the characteristics of the learner change over time, much like that of best teaching practices or even broad cultural changes (Stevens, 2011). To reflect this development, the ubiquitous term "21st century learner", which stems from futurists, has recently come into existence (Stevens, 2011). The first-year experiences of present students are a mix of high-level educational demands coupled with an environment 
of uncertainty and unknowns. A common experience for 21st century students consists of large class sizes and novel lesson formats (Cuseo, 2007). These emerging formats include online education and online learning support tools.

Researchers have identified the institutional importance of understanding how to teach the 21st century 'digital native' student (Prensky, 2001; Cowling, 2015). Advances in this area have yielded an increased number of first-year courses that include technology such as online seminars, flipped classes, blended learning, and online lectures (Padgett, Keup, \& Pascarella, 2013; Sriarunrasmee, Techataweewan, \& Panichkul Mebusaya, 2015). Many of these technologies brought into course design are intended to improve accessibility to courses and materials, as well as provide support for a wider range of student learning preferences. The success of these developments has been mostly supported by recent literature; however, some studies are pushing back against these developments (see Beland \& Murphy, 2015). Overall, educational researchers advise further exploration into these new technological-pedagogical developments as necessary for understanding the impact on first-year student retention rates (Sriarunrasmee, Techataweewan, \& Panichkul Mebusaya, 2015).

Recent research by Gallardo-Echenique, Bullen, and Marques-Molias (2016) explored tool use and study habits of 204 first-year students from four post-secondary institutions in Canada and Spain. They identified that students often use a variety of methods including email, face-to-face discussions, and Facebook to communicate with peers and professors. The use of technology as a communication tool suggests that it is common for today's students to mix methods that they find helpful and to which they have easy access. Sriarunrasmee, Techataweewan, and Panichkul Mebusaya (2015) further support this finding in their discussion of e-learning and social networks as learning tools for a sample of 84 first-year university students. The relationship between these technological-pedagogical developments and successful transitions to university learning is a flourishing research area. These perspectives on the learning needs of the 21 st century students were integral to framing this research project.

\section{Method}

This project spanned 18 months and included studying the first-year academic experience across four perspectives (and in four phases): faculty perspective; student service staff perspective; student perspective (both first and second year); and an environmental scan of 92 syllabi. The study used a mixed method design and relied on self-reporting through reflection.

In terms of phase one, the faculty perspective, the first survey was completed by 122 instructors. All 122 instructors had experience teaching first year courses (level 1000), and the survey returned a response rate of $53 \%$. Once the survey was completed, the data was automatically collated in Qualtrics. The second questionnaire asked instructors three questions: 1) What are the positives of teaching 1 st year courses? 2) What are the challenges of teaching 1st year courses? 3) What is one wish you have for 1st year teaching?

In July 2015, the second phase of the FirstYear Academic Experience project commenced, where we sought out the student support staff perspective. A survey was disseminated to members of the University community who provide student academic supports including: academic skills; academic advisors; spiritual affairs; Indigenous student support; health and counselling services, disability services; and colleges. The survey was distributed to 34 academic student support staff, based on discussion with administration. Sixteen of the academic student support staff responded.

The third phase of the project was designed to elicit student perspectives, and began in January 
2016. Two surveys were created to capture student voice. We were interested in gathering student insights from two vantage points: 1) students who were currently enrolled in their first year at the University, and 2) students who had completed their first year at the University and were now enrolled in second year studies, reflecting on their previous year. The students were given a survey with four questions specific to their academic experience.

1) Describe two academic highlights of your first-year experience at the University. (courses, professors, programs, assignments, field trips, labs etc.)

2) Describe one disappointment about your first-year experience at the University.

3) If you could change one thing about your first-year experience at the University, what would it be?

4) On a 5-point scale: Overall, my first-year experience at the University has been...

i. Engaging (strongly disagree to strongly agree)

ii. Challenging (strongly disagree to strongly agree)

iii. Terrific (strongly disagree to strongly agree)

The survey was distributed through the Office of Student Affairs to all enrolled first-year and second-year students. One hundred and sixty-six students from the first-year cohort responded. One hundred and forty students from the second-year cohort responded. The second-year student survey asked the same questions as the first-year student survey; however, they were presented in the form of reflection: "Reflecting on your first year at the University, please complete the following questions..." Overall, the response rate was approximately $10 \%$.

Our results from the first three phases raised additional research questions. What do the first-year course syllabi look like? What teaching formats are used? What types of assessments are used? With this in mind, we added an additional phase to the project in January 2016. From the 2015-2016 academic term (September 2015-April 2016), a total of 92 first-year course syllabi were shared from 21 departments for further analysis (with an almost $100 \%$ compliance rate).

The first three phases of the project relied on data collected through self-reporting. Podsakoff and Organ (1986) argue that although self-reporting is prone to biases, it is an effective method of data collection for capturing participants' perspective of how organizations function. Data was also collected via retrospective self-reporting for the second-year students. According to Lam and Bengo (2003), retrospective self-reporting is an effective measure of a participant's perspective and personal accounts of an experience if the questions require minimal effort in responding. The questions were therefore designed to be general, open-ended questions that the respondents could answer with minimal recall demands. Woo, Kim, and Couper (2015) report that using web-based surveys are ideal for students in tertiary education since internet access is near universal for this population and the response rate is relatively high. For more on the rapid growth of electronic survey use with university students, see Couper and Miller (2008).

\section{Findings}

The faculty perspective captured through the online survey identified both highlights and challenges of teaching first-year courses at the University. Faculty reported that the positive aspects of teaching first-year students included having the opportunity to be involved in the introduction of students to university life and in students' first university-level encounter of their discipline. Faculty also reported seeing the value and responsibility of supporting students in making 
connections with peers, departments, and the institution overall.

On the other hand, faculty also reported on, and discussed, several challenges to teaching first-year courses including: volume of administrative tasks such as email and learning management system tasks; departmental expectations such as preparing students for upper year courses; teaching pedagogy limitations when working with large class sizes; difficulty building forms of engagement with students; challenges keeping advanced students interested in the subject; limited space such as lack of flexibility in classrooms and reliance on over-flow rooms; dwindling student attendance patterns; and the variability of student preparedness.

The student academic support staff perspective yielded additional interesting findings, highlighting the growing complexity and challenges many of our first-year students face while pursuing their academic endeavours. The staff reported that the main issues brought forward by first-year students included: academic challenges, life transition difficulties, conduct and behavioural issues, emotional issues, social problems, mental health issues, under preparedness for university, and difficulty navigating course requirements. The staff reported that many of the meetings with students involved challenges that required considerable time to address.

When we examined the perspectives of students, the first-year students reported several highlights of their first-year courses at the University. Clustered and in ranked order were: program or discipline specific highlights; instructor/faculty/TA interactions and learning; a sense of personal academic accomplishment; involvement in campus communities; academic supports; and participating in college life. Table 1 below presents the frequency of responses per categories.
Table 1

Frequency per category of academic

highlight reported by 1st year students (multiple

responses

\begin{tabular}{lrr}
\hline Node & $\%$ & Count \\
\hline Program/ discipline specific & $39 \%$ & 76 \\
\hline Professors/ instructors/ TA's & $31 \%$ & 61 \\
\hline Academic accomplishment & $12 \%$ & 22 \\
\hline Campus community & $12 \%$ & 23 \\
\hline Academic support & $7 \%$ & 14 \\
\hline College life & $1 \%$ & 2 \\
\hline & $100 \%$ & 198 \\
\hline$n=166$ & & \\
\hline
\end{tabular}

To further elaborate on the meaning of each of these categories, an illustrative quote from first year students are provided for each category.

Program: "Being able to delve into my field of study with such pace is both exhilarating and intimidating all the same. Nonetheless, when passionate about a subject one can't help but become excited go such a higher stage of learning." (1st year student)

Professor: "Two of my profs were absolutely amazing and very helpful with transitioning into the university world. They were understanding and explained everything in great detail to make sure that all their students had the best first semester experience they could have." (1st year student)

Academic accomplishment: "Getting to do a Lab in the Crime Scene House in FRSC1010." (1st year student)

Campus Community: "There was such a wonderful, encouraging and excited feeling about campus. It really was walking around with other people who (no matter how sleep-deprived or stressed) were genuinely happy to be there. That simply is not comparable to anything: that feeling that the community is full of love for their university, and each other." (1st year student) 
Academic Support: "The academic advisor is both knowledgeable and helpful. I had so many questions and concerns about my timetable and they were able to both talk me through and assist me with organizing the schedule that worked best for me!" (1st year student)

College: "O week! It was a great way to meet people and get over the initial awkwardness of being in a new place." (1st year student)

The survey also provided insight into the reported challenges of their first-year courses at the University. Clustered and in ranked order, these included experiencing course disappointments; experiencing instructor/faculty/TA issues; difficulty with assessment and evaluation issues; overall academic difficulties; financial stressors; heavy workloads; lack of space; and a general lack of preparation or skills for university academics. See Table 2 below.

Table 2

Frequency per category of academic challenges reported by 1st year students

\begin{tabular}{lcr}
\hline Node & $\%$ & Count \\
\hline $\begin{array}{l}\text { Professor/ instructor/ TA } \\
\text { issues }\end{array}$ & $23 \%$ & 21 \\
\hline Course disappointments & $18 \%$ & 17 \\
\hline $\begin{array}{l}\text { Assessment \& evaluation } \\
\text { issues }\end{array}$ & $11 \%$ & 10 \\
\hline Academic difficulties & $11 \%$ & 10 \\
\hline Lack of prep or skills & $3 \%$ & 3 \\
\hline Financial & $3 \%$ & 3 \\
\hline Workload & $2 \%$ & 2 \\
\hline$n=140$ & $100 \%$ & 93 \\
\hline
\end{tabular}

When asked to reflect on their first-year experience, the second-year students reported several highlights of their first-year courses at the University. Clustered and in ranked order were: program/discipline specific highlights; positive
instructor/faculty/TA encounters; personal academic accomplishments; positive campus communities; availability of academic supports; and involvement with college life. The data cluster and ranked order were the same as first-year students with minimal variance. The survey also provided us insight into the reported challenges the second-year students remembered about their first-year courses at the University. Clustered and in ranked order were: difficult instructor/faculty/TA issues; course disappointments; both assessment and evaluation issues and academic difficulties; financial stressors; general lack of preparation or skills; and challenging workloads. There was an increase in reported challenges with instructors/faculty/TAs by the second-year students; however, the other reported challenges were relatively consistent compared to first-year students. See Table 3 below.

\section{Table 3}

Frequency per category of academic challenges reported by 2nd year students

\begin{tabular}{lrr}
\hline Node & $\%$ & Count \\
\hline $\begin{array}{l}\text { Professor/ instructor/ } \\
\text { TA issues }\end{array}$ & $23 \%$ & 21 \\
\hline $\begin{array}{l}\text { Course } \\
\text { disappointments }\end{array}$ & $18 \%$ & 17 \\
\hline $\begin{array}{l}\text { Assessment \& } \\
\text { evaluation issues }\end{array}$ & $11 \%$ & 10 \\
\hline Academic difficulties & $11 \%$ & 10 \\
\hline Lack of prep or skills & $3 \%$ & 3 \\
\hline Financial & $3 \%$ & 3 \\
\hline Workload & $2 \%$ & 2 \\
\hline$n=140$ & $100 \%$ & 93 \\
\hline
\end{tabular}

To further elaborate on the meaning of each of these categories, illustrative quotes from second year students are provided for each category. Professor: "Profs are hard to follow 
sometimes and do not always seem approachable." (2nd year student)

Course disappointments: "I thought coming into university that my major would be psych but my experience with was miserable I feel like I didn't learn anything and the content was too dense to even get into!" (2nd year student)

Assessment $\&$ evaluation: "Exams that were fully multiple choice. These exams do not allow for the student to explain their logic to their answers and are very right or wrong based, especially with more complex topics." (2nd year student)

Academic difficulties: "I was very surprised at how much my grades dropped from high school to university. I don't think I was mentally prepared for that at all, but I pushed through and learned what I needed to do to stay afloat." (2nd year student)

Lack of skills: "It was much easier for me to slack off and skip class so I took advantage of that, not having done it in high school, though this is more of a personal disappointment rather than one with the academics themselves." (2nd year student)
Workload: "Readings built up quickly, and some of my seminars were too large for me to really participate." (2nd year student)

Financial: "The cost of textbooks." (2nd year student)

When we performed an environmental scan of 92 first-year course syllabi, the data scan yielded further results related to course assessment (See Table 4). A total of $96 \%$ of the first-year courses had a final exam, $86 \%$ had a midterm exam, $37 \%$ included class quizzes, and $14 \%$ had online quizzes. We concluded that the most common form of assessment was testtaking. The majority of the tests were reportedly conducted using Scantron test formats. The average weight of midterm tests was $21.2 \%$ of the final grade with a range of $10-30 \%$. Weight of the final exams averaged at $31.4 \%$ with the range of $20-50 \%$ of the course evaluation. When due dates and final exam grades were combined, the average weight of work submitted in the final two weeks of class averaged at $49 \%$ (with a range of $28-65 \%$ of the weighting occurring in the final two weeks).

Table 4

Types of assessments reportedly used in 1st year courses ( $n=92$ )

\begin{tabular}{l|l|l}
\hline Types of Assessments & Count & $\begin{array}{l}\% \text { of courses that use said form of } \\
\text { assessment }\end{array}$ \\
\hline Final Exam & 88 courses & $95.70 \%$ \\
\hline Midterm Test & 79 courses & $85.90 \%$ \\
\hline Assignment or project (not research specified) & 57 courses & $62 \%$ \\
\hline Course participation grade & 47 courses & $51.10 \%$ \\
\hline Research paper or essay & 37 courses & $40.20 \%$ \\
\hline Quizzes (in class) & 34 courses & $37 \%$ \\
\hline Online quizzes & 13 courses & $14.10 \%$ \\
\hline Group assignment/ group presentation & 8 courses & $9 \%$ \\
\hline Individual presentations & 6 courses & $7 \%$ \\
\hline Online Post/ Discussion & 3 courses & $3.30 \%$ \\
\hline Portfolio & 1 course & $1.10 \%$ \\
\hline Reflection piece & 1 course & $1.10 \%$ \\
\hline
\end{tabular}

Table 5 reports the weighting of tests and assessments with the percentage of the grade assigned within the last 2 weeks of the course. Row 4 of Table
5 expresses the range and average weight of evaluations which occur during the final 2 weeks of the course as well as the exam. According to the 
syllabi, students in first year courses complete anywhere from $2 \%-35 \%$ of their final course mark in the last two weeks of the course. When we include the exams, students complete a range of $28 \%-65 \%$ of their final grade at the end of the course.

\section{Table 5}

Weighting of test, assessments and percentage of grade within the last 2 weeks of the course (n=92)

\begin{tabular}{l|l|l}
\hline Assessment & Range & Average weight \\
\hline Weight of Midterm Test(s) & $10 \%-30 \%$ & $21.2 \%$ \\
\hline Weight of FINAL EXAM & $20 \%-50 \%$ & $31.4 \%$ \\
\hline$\%$ of Grade due in last TWO WEEKS & $2 \%-35 \%$ & $19 \%$ \\
\hline$\%$ of Grade due in last 2 weeks including exam & $28 \%-65 \%$ & $49 \%$ \\
\hline
\end{tabular}

The syllabi data is consistent with the Instructor data from Phase 1 which shows that $88 \%$ of courses are reportedly lecture based, $35.9 \%$ have a weekly seminar/ tutorial component, $12 \%$ have a fortnightly lab component, $9.8 \%$ have workshops,
$8.7 \%$ have weekly labs, $6.5 \%$ have seminar/ tutorial (fortnightly), 5 courses were online and 5 courses reported had a practical learning/ field trip/ clinical component as shown in Table 6.

Table 6

Course format reportedly used in 1st year courses (n=92) - multiple formats per course included

\begin{tabular}{l|l|l}
\hline Types of course formats & Count & $\%$ of courses using said format \\
\hline Lecture & 81 courses & $88 \%$ \\
\hline Seminar/ tutorial (weekly) & 33 courses & $35.90 \%$ \\
\hline Lab (fortnightly) & 11 courses & $12 \%$ \\
\hline Workshop & 9 courses & $9.80 \%$ \\
\hline Lab (weekly) & 8 courses & $8.70 \%$ \\
\hline Seminar/ tutorial (fortnightly) & 6 courses & $6.50 \%$ \\
\hline Online course & 5 courses & $5.40 \%$ \\
\hline $\begin{array}{l}\text { Practical learning/ field trip/ } \\
\text { clinical }\end{array}$ & 5 courses & $5.40 \%$ \\
\hline
\end{tabular}

\section{Discussion - What did we learn?}

Faculty enthusiastically reported several benefits to teaching first-year courses. For example, faculty reported deep personal satisfaction from introducing their field of study to new students. Instructors saw themselves in many cases as the embodied introduction to their fields and valued leading the first university subject encounter for first-year students. Concurrently with the positive aspects of teaching first-year courses, faculty also reported that there were some specific challenges. These challenges included administrative tasks that interfered at times 
with their course planning time. Faculty also noted that their teaching pedagogy was limited as a result of teaching large classes in spaces that were not flexible. Faculty noted it was difficult to engage in active learning techniques when several hundred students are in a room where the chairs are affixed to the floor (not moveable). Another challenge reported by faculty involved finding strategies to keep advanced students engaged and interested in the subject. Faculty also expressed interest in learning more about what first-year courses were like in other disciplines and wanted opportunities for collaboration.

The student academic support staff contributed an interesting frontline perspective about the first-year learning experience at the University. Similar to faculty findings, there is a parallel expression of both benefits and challenges to supporting first-year learners. The major findings of the staff perspective captured the complexity of the students and the student difficulties navigating academic requirements. Staff reported that $87.5 \%$ of the students they see are experiencing academic distress and $75 \%$ of the students were in distress outside their academics as well. Student complexity reportedly took on many forms including underpreparedness both academically and personally for university studies. It was also noted that students experienced significant difficulty navigating course selection, drop dates, degree requirements, prerequisites, program requirements, academic supports and accessing resources and services.

Both the first-year student and the secondyear student data sets reported similar findings across all main areas. One major theme that came forward for both sets of students was the notion of wanting to be more involved. Student involvement can be linked with student engagement. The psychological component of student engagement includes a sense of belonging. If students are not engaged, then they tend to feel that they do not belong; if students feel that they do not belong, then they are less likely to participate and engage, so it becomes a cycle of continued alienation for students who do not feel that their beliefs and values are recognized and valued by their educational institution (Krause \& Coates, 2008). Orientation is an excellent starting point for fostering student engagement; however, it is also important that this focus continues throughout the student's first-year, as the student's needs will change at different points throughout the academic year. This finding suggests that the University may need to make the effort to further understand the detailed experiences and needs of first-year students in order to recognize which actions need to be taken and at what times throughout the year.

The environmental scan of the course syllabi captured basic course design approaches for first-year courses at the University. We found the assessment practices in first-year courses to be of interest. The most common form of assessment is clearly test taking. This practice of assessment may be in part due to the number of students who require evaluation in first-year courses. The heavy weighting of grades on exams, and late in the course, is of concern. Assuming that a first-year student is taking five courses, $50 \%$ of all their grades are conducted within a two-week timeframe at the exam period. This results in significant stress, impacts authentic learning, and affects student success and retention (Bask \& Salmela-Aro, 2013).

Non-exam written forms of assessment were significantly lower: $62 \%$ of courses had a written component, and of the $62 \%$ of the courses with this written final assessment, $40 \%$ had a research paper component not conducted in a test-taking scenario. Some courses also included group assignments and individual presentations.

\section{Way Forwarding}

As articulated in the University's mission and vision statements, the University is deeply committed to 
providing students with a personalized, purposeful and transformative learning experience. The University was designed to nurture individual students and to support them in their unique pathway, and now with more insight into the current trends and practices of our first-year courses, we have identified some strategies for addressing the current complexities of learners in a rapidly growing institution.

In the spring of 2017, the Centre of Teaching and Learning hosted a Faculty Teaching Retreat. The aim of this one-day retreat was to take first-year faculty outside of the institution and engage in professional development and self-care. The day consisted of round table sessions on teaching efficacy, course design, dealing with challenges in the classroom and incorporating universal instructional design into large classes. Intermixed between the traditional PD sessions were sessions of yoga, mindfulness, mediation, and play (in the form of mini-golf). The retreat also sought to establish communities of practice for peer support. The day brought the faculty together and was a tremendous success as reported by those who participated. Upon reflection, participants shared that they felt valued and supported, could recharge, and left feeling renewed and excited about teaching their first-year class. Participants also commented that the opportunity to meet faculty from other disciplines and explore the similarities of challenges and benefits was rewarding. This interdisciplinary approach was effective to validate the first-year teaching experience and build community.

The Centre for Teaching and Learning is exploring frameworks for wise practices for designing and teaching first-year courses. Informed by the works of Erickson, Peters and Strommer (2006), we are developing a series of guiding principles. Themes include: providing feedback early and often; posing complex, real life problems; minimizing memorization; teaching critical thinking; clarifying expectations for learning; preparing for emotional reactions; using multi-modalities of instruction; designing for a variety of learning styles; and promoting student reflection. These principles can be viewed as strategies for faculty to consider within their teaching practices. Unlike the research that discusses first-year learning solely from the student perspective, these principles lay out a focus for the instructor. Including a focus for instructors is a significant shift from the responsibility for learning lying solely with the student. Instead, it encourages the instructor to take an active role in the first-year course beyond the traditional knowledge transfer.

Lastly, the University is investigating how to develop and facilitate professional learning communities (PLCs) for faculty who teach first-year courses. Over the past two decades, the educational literature has devoted significant attention to the topic of professional learning communities (PLCs) and how they can be successfully incorporated into faculty development. The underlying philosophy of PLCs is anchored in the belief that student learning can be improved by improving teaching practice (Vescio, Ross \& Adams, 2007). The literature provides convincing evidence of the benefits of PLCs such as improving the teaching culture of an organization (Vescio et al., 2007), increased student achievement (Lomos et al., 2011), reduced teacher isolation, increased peer learning, increased knowledge of effective teaching strategies, and greater job satisfaction (Annenberg Ins., 2004). Cox (2012) recommends that PLCs be specifically structured, year-long academic communities of practice with shared goals of building a teaching community, engaging in scholarly (evidenced-based) teaching practices, and developing scholarship on teaching and learning. This fall, the CTL has rolled out the University Teaching Scholars' Community of Practice. This group is developing a research cycle with faculty focused on their teaching practices through collaborative learning and skill development. It is our aim to build community with just-in-time learning for instructors who want to conduct 
scholarship on their teaching practice with the ultimate goal of improving the learning experience for the students. A generous donation to the Centre for Teaching and Learning is a part of this initiative to support excellence in teaching at the University.

\section{Conclusion}

Having a deeper understanding of the first-year academic experience was crucial for us. We wanted to know how to best support our students and our facility. The theoretical frameworks and research around first-year student learning such as transitions, engagement, motivation, retention, and 21st century learning are important to understand; yet we wanted to go a step further to have a better sense of what the experience was like at our institution and from multiple perspectives.

This collaborative study was possible because of the very nature of the University being interdisciplinary. This interdisciplinarity is one of our strengths. Another strength is the openness of our colleagues and students to participate when called upon. Our research approach was rather direct - let's ask them, and that is what we did. We heard from faculty about the privilege of being able to introduce students to their disciplines and the challenges of teaching larger classes, accompanied by the administrative work loads that accompany growing numbers of students in each class. Student support staff shared the joys of helping students achieve their goals and succeed in their courses, all the while being aware of the growing complexity of student needs. The students voiced their excitement at starting their academic journey while navigating competing pressures by outside demands, and wishing they could get more involved. We asked and our community responded.

With this information, and the generous financial gift to our Centre for Teaching and Learning, we can introduce strategic initiatives, anchored in communities of practice, such as the Teaching Retreat and the Teaching Scholars' Community of Practice. We are also able to develop a suite of services and resources, guided by scholarly practices, for teaching first-year courses and students. As the University enters the next chapter, the tradition of quality first-year academic experiences continues to be fostered, recognized, and celebrated.

\section{References}

Annenberg Institute. (2004). Professional Learning Communities: Professional Development Strategies That Improve Instruction. Retrieved from http://www.annenberginstitute.org/publicat ions/professional-development-strategiesprofessional-learningcommunitiesinstructional-coach

Ames. C. A. (1990). Motivation: What Teachers Need to Know. Teacher's College Record. 91(3). 409-422.

Asmar, C., Page, S., \& Radloff, A. Exploring Anomalies in Indigenous Student Engagement: Findings from a National Australian Survey of Undergraduates. (Higher Education Research \& Development, in press).

Barnes, S., Macalpine, G., \& Munro, A. (2015). Track and Connect: Increasing first year student engagement, retention and success at the University of Sydney. JANZSSA, 45, 12-19.

Bask, M. \& Salmela-Aro, K. (2012). Burned out to drop out: Exploring the relationship between school burnout and school dropout. European Journal of Psychology Education, 28(2), 511-528.

Beland, L., \& Murphy, R. (2015). III Communication: Technology, distraction \& 
student performance. London School of Economics and Political Science. Discussion Paper \#1350. ISSN 2042-2695.

Boote, D. \& Beile, P. (2005). Scholars before researchers: On the centrality of the dissertation literature review in research preparation. Educational Researcher, 34, 315.

Carini, R.M., Kuh, G.D., \& Klein, S.P. (2006). Student engagement and student learning: Testing the linkages. Research in Higher Education, 47(1), 1-32.

Couper, M. P., \& Miller, P. V. (2008). Web survey methods. Public Opinion Quarterly, 72, 831-835.

Cox, M. D., Richlin, L. and Essington, A. (2012). Faculty Learning Community Planning Guide. Los Angeles, CA: Alliance Publishers.

Cowling, M. A. (2015). Models for the successful integration of social networking into the studies of digital native students. Journal of the Australia and New Zealand Student Services Association, 45, 20-30.

Cuseo, J. (2007). The empirical case against large class size: Adverse effects on the teaching, learning, and retention of first-year students. The Journal of Faculty Development, 21(1),5-21.

Nelson, K. J., Kift, S., \& Clarke, J. A. (2008, JuneJuly). Expectations and realities for first year students at an Australian university. Paper presented at the 11th Pacific Rim First Year in Higher Education Conference, "An Apple for the Learner: Celebrating the First Year Experience." Hobart, Tasmania.

Erickson, B., Peters, C., \& Strommer, D. (2006). Teaching First-Year College Students: Revised and Expanded Edition, Jossey-Bass.
Gallardo-Echenique, E., Bullen, M., MarquesMolias, L. (2016). Student communication and study habits of first-year university students in the digital era. Canadian Journal of Learning and Technology, 42(1), 2-21.

Kantanis, T. (2000). The role of social transition in students' adjustment to the first-year of university. Journal of Institutional Research, 9(1), 100-110.

Krause, K., \& Coates, H. (2008). Students' engagement in first-year university. Assessment and Evaluation in Higher Education, 33(5), 493-505.

Lam, T. \& Bengo, P. (2003). A comparison of three retrospective self-reporting methods of measuring change in instructional practice. American Journal of Evaluation, 24, 65-80.

Latham, G., \& Green, P. (1997). The journey to university: A study of the first year experience. Retrieved from http://ultibase.rmit.edu.au/Articles/dec97/g reenlath1.htm

Lomos C, Hofman R, Bosker, R. (2011) Professional communities and student achievement: a meta-analysis. School of Effectiveness and School Improvements, 22(2), 121-148.

Padgett, R. D., Keup, J. R., \& Pascarella, E. T. (2013). The impact of first-year seminars on college students' life-long learning orientations. Journal of Student Affairs Research and Practice, 50(2), 133-151.

Parkin, A., \& Baldwin, N. (2009). Persistence in post-secondary education in Canada: The latest research. Millennium Research Note \#8. Montreal, PQ: Canada Millennium Scholarship Foundation.

Podsakoff, P. \& Organ, D. (1986). Self-reports in organizational research: Problems and prospects. Journal of Management, 12, 531544. 
Prensky, M. (2001). Digital natives, digital immigrants. On the Horizon, 9(5), 1-15.

Schlossberg, N. K. (1981). Major contributions. Counseling Psychologist, 9(2), 2-15.

Sriarunrasmee, J., Techataweewan, W., \& Panichkul Mebusaya, , R.. (2015). Blended learning supporting self-directed learning and communication skills of Srinakharinwirot University's first year students. Social and Behavioral Sciences, 197, 1564-1569.

Stevens, M. (2011). 21st century learner. 21stCentury Classroom Exhibit at NEA's Representative Assembly. Retrieved from: http://ftp.arizonaea.org/home/46989.htm.

Vescio, V., Ross, D., Adams, A. (2007) A review of research on the impact of professional learning communities on teaching practice and student learning. Teaching and Teacher Education, 24, 80-91.

Willms, J.D. (2003). Student engagement at school: A sense of belonging and participation (results from PISA 2000). Organisation for Economic Co-operative and Development.

Woo, Y., Kim, S., \& Couper, M. (2012). Comparing a cell phone survey and a web survey of university students. Social Science Computer Review, 33(3), 399-410. 